\title{
Upaya Membangun Guru Profesional Berkarakter di Era Globalisasi Melalui Pembelajaran
}

\author{
Sulastri Rini Rindrayani \\ Dosen Dpk Pada STKIP PGRI Tulungagung
}

rrindrayani@yahoo.com, Dosen STKIP PGRI Tulungagung Program Studi Pendidikan Ekonomi

\begin{abstract}
ABSTRAK: Tantangan globalisasi yang harus dihadapi guru dengan mengedepankan profesionalismenya adalah (1) perkembangan ilmu pengetahuan dan teknologi yang begitu cepat dan mendasak, (2) Krisis moral yang melanda Indonesia, akibat pengaruh IPTEK dan globalisasi telah terjadi pergeseran nilai-nilai yang ada dalam kehidupan masyarakat, (3) Krisis sosial, seperti kriminalitas, kekerasan, pengangguran, dan kemiskinan yang terjadi dalam masyarakat. Akibat perkembangan industri dan kapitalisme, maka muncul masalah-masalah sosial dalam masyaraka, (4) Krisis identitas sebagai bangsa dan Negara Indonesia. Guru professional harus mampu menyesuaikan diri secara responsive, arif, dan bijaksana terhadap tantangan global tersebut sehingga mampu berperan dalam menghasilkan pendidikan berkualitas dan berkarakter. Impelentasi guru professional berkarakter akan dapat dilihat dari pelaksanaan kompetensi yang dimilki dalam kehidupan seharihari baik kompetensi pendagogik, kompetensi kepribadian, kompetensi sosial, dan kompetensi professional. Hanya guru professional berkarakter yang dapat menghasilkan peserta didik berkualitas dan berkarakter. Salah satu cara strategis dalam membagun guru professional berkarakter di era globalisasi dilakukan melalui pembelajaran. Kegiatan pembelajaran yang dilakukan oleh guru, mulai dari perencanaan, pelaksanaan, dan evaluasi merupakan kegiatan guru sebagai bukti riil keprofesiannya dalam menerapkan kompetensi pendagogik, kompetensi professional, kompetensi sosial, dan kompetensi kepribadian. Pada pembelajaran inilah guru perlu mengembangkan nilai-nilai karakter dalam dirinya agar dapat membentuk siswa berkarakter. Guru tidak hanya menjadi pendidik dan pengajar bagi siswa, namun mereka mampu menjadi teladan bagi siswa.
\end{abstract}

Kata Kunci “ Guru Professional, Berkarakter, Globalisasi, Pembelajaran”

\section{PENDAHULUAN}

Sesuai dengan Undang-Undang Guru dan Dosen no 14 tahun 2005, pasal 4 menjelaskan bahwa Kedudukan guru sebagai tenaga profesional pada jenjang pendidikan dasar, pendidikan menengah, dan pendidikan anak usia dini pada jalur pendidikan formal berfungsi untuk meningkatkan martabat dan peran guru sebagai agen pembelajaran berfungsi untuk meningkatkan mutu pendidikan nasional. Pada 6 undang Guru dan Dosen No 14 tahun 2005 juga disebutkan bahwa kedudukan guru tenaga professional bertujuan melaksanakan sistem pendidikan nasional dan mewujudkan tujuan pendidikan nasional, yaitu berkembangnya potensi peserta didik agar menjadi manusia yang beriman dan bertakwa kepada Tuhan Yang Maha Esa, berakhlak mulia, sehat, berilmu, cakap, kreatif, mandiri, serta menjadi warga negara yang demokratis dan bertanggung jawab $\mathrm{Hal}$ ini dapat diartikan bahwa guru sebagai tenaga professional mempunyai peran yang strategis pada pendidik dasar dan menengah untuk melaksanakan kegiatan pembelajaran pada peserta didik, sehingga dapat mengembang-kan potensi peserta didik agar menjadi manusia yang beriman dan bertakwa kepada Tuhan Yang Maha Esa, berakhlak mulia, sehat, berilmu, cakap, kreatif, mandiri, serta menjadi warga negara yang demokratis dan bertang-gung jawab. Jadi guru sebagai agen pembelajaran tidak hanya memberikan pengetahuan, ketrampilan, tetapi juga sikap yang dapat digunakan peserta didik untuk mampu mandiri dan menyesuaikan diri dengan lingkungan dan kebutuhan.

Namun demikian dalam mengembankan tugas profesinya guru belum maksimal, walaupun sebenar pihak pemerintah berusaha untuk menigkatkian kualitas keprofesiannya. Sebagai bukti upaya pemerintah dalam meningkatkan professional guru adalah (1) diberikannnya sertifikat mengajar sebagai bukti 
guru yang memiliki kompetensi pendagogik, kompetensi professional, kompetensi sosial dan kompetensi kepribadian kepada guru yang sudah mengajar baik melalui jalur portofolio ataupun PLPG; (2) Dibentuknya Musyawarah Guru mata Pelajaran sebagai sarana untuk berkomunikasi antara guru bidang studi untuk meningkatkan kualitras pembelajaran; (3) Diwajibkannya guru membuat karya tulis dalam bentuk Penelitian Tindakan Kelas (PTK) atau penelitian lainnya untuk pengajuan kenaikan pangkat mulai golongan IVa, hal ini meuntut guru berupaya meningkat pengetahuan dan ketrampilan dalam melakukan penelitian; (4) Mewajibkan bagi guru yang memeperoleh tunjangan profesi untuk mengajar sebanyak 24 jam.

Upaya pemerintah untuk meningkatkan kualitas guru tersebut tidak diimbangai demgan kemampuan guru dan kondisi sekolah yang mendukung mengakibatkan timbulnya masalah rendahnya professional guru. Hal ini terbukti banyak guru yang tidak melaksanakan kewajibannya dalam mengajar dengan optimal. Permasalah tersebut merupakan masalah internal guru antara lain (1) kemampuan guru yang masih rendah dalam membuat karya tulis PTK yang merupakan gambaran kemampuan guru dalam menemukan masalah pada saat melaksanakan pembelajarandan bagaimana cara mengatasi masalah tersebut; (2) adanya ketentuan mengajar 24 jam bagi guru yang memperoleh tunjanga profesi mengakibatkan guru yang tidak terpenuhi mengajar sejumlah 24 jam di sekolahnya, maka guru tersebut harus mencari di sekolah lain agar terpenuhi 24 jam. Dampaknya guru lebih difokuskan untuk mencari tempat mengajar agar terpenuhi 24 jam daripada mempersiapkan diri materi dan perangkat lain untuk mengajar; (3) Masih adanya guru yang mengajar mata pelajaran tidak sesuai dengan bidang ilmunya, misalnya sarjana pendidikan ekonomi mengajar mata pelajaran kesenian, akibatnya guru tidak bisa menguasai materi; (4) Rendahnya motivasi guru dalam menyiapkan diri dalam mengajar, misalnya guru tidak membuat RPP, buku ajar, instrument penilaian yang merupakan perangkat guru dalam mengajar.

Selain guru memiliki masalah internal dalam menjalankan keprofesiannya, guru juga menghadapi masalah eksternal yaitu tututan global yang harus disikapi, yaitu bebasnya masuk arus barang, tenaga kerja, modal, investasi, teknologi dari berbagai negara lain di Indonesia. Globalisasi ini akan berdampak positif dan negatif. Berdampak positif apabila mampu menyesuaikan diri dan mampu menggunakan hal-hal yang baru, misal dapat menyesuaikan diri dengan kemajuan teknologi. Berdampak negatif bila hal-hal yang baru tersebut diterima begitu saja tanpa difilter dengan nilai-nilai budaya kita yang merupakan pencerminan karakter bangsa Indonesia. Kondisi di lapangan masih rendahnya guru dalam menyesuaikan diri dengan pengaruh globalisasi, sehingga penerapan guru professional berkarakter yang dapat menghasilkan peserta didik berkualitas dan berkarakter belum terwujud sesuai yang diharapkan.

Tentunya guru professional akan menyikapi kondisi tersebut dan berusaha bagaimana peserta didiknya dapat menerima ilmu pengetahuan, ketrampilan, dan sikap yang mencerminkan karakter bangsa dengan baik. Peran guru sebagai pendidik sangat strategis untuk peningkatkan pendidikan melalui pembelajaran, sehingga menghasilkan peserta didik yang berkualitas dan perkarakter.

Berdasarkan permasalah tersebut di atas maka perlu upaya untuk membangun guru profesional berkarakter di era globalisasi melalui pembelajaran. Guru yang professional berkarakter positif akan dapat melaksanakan pembelajaran berkarakter kepada peserta didiknya. Artinya dalam pembelajaran guru tidak hanya memberikan materi tetapi guru juga memberikan tauladan baik sikap, perkataan, dan perbuatan kepada peserta didik.

\section{PEMBAHASAN}

\section{Globalisasi}

Globalisasi adalah Keterkaitan ketergantungan antar bangsa dan antar manusia di seluruh dunia melalui perdagangan, investasi, perjalanan, budaya populer, dan bentuk- bentuk interaksi yang lain sehingga suatu batas -batas suatu negara menjadi bias (Prihastuti, 2013: 35). Pendapat lain Syakur (2012:11) "global" berarti sedunia atau sejagat, menyeluruh (mujmal), universal. Kata tersebut selanjutnya menjadi istilah yang merujuk kepada suatu kedaan di mana suatu negara dengan negara lain sudah menyatu. Batas-batas teritorial, kultural, dan 
sebagainya sudah bukan merupakan hambatan lagi untuk melakukan

penyatuan tersebut. Dengan demikian dapat diartikan globalisasi merupakan suatu kondisi terjadinya arus bebas tenaga kerja, modal, investasi, budaya, sosial, politik dari berbagai negara di dunia sehingga suatu batas-batas suatu Negara menjadi bias. Kondisi global ini berdampak pada globalisasi perekonomian, globalisasi bidang politik, globalisasi bidang budaya, dan gloalisasi bidang sosial.

Timbulnya globalisasi ini akan berdampak positif dan negatip. Dampak positif Globalisasi menurut Prihastuti (2013: 37) adalah (1)Memperoleh informasi dan penambahan ilmu pengetahuan alam maupun social akan mudah di jangkau bagi setiap individu di berbagai belahan dunia manapun; (2) Jalinan komunikasi akan semakin mudah dan semakin canggih; (3) Mobilitas yang tinggi akan memudahkan siapapun di era globalisasi akan mudah dalam melakukan perjalanan baik perjalanan jauh maupun perjalanan pendek dengan adanya alat transportasi yang semakin beragam; (4) Sikap kosmopolitan ataupun toleransi antara satu individu dengan individu yang lain akan meningkat; (5)Perkembangan tekhnologi. Sedangkan Dampak negatif Glo-balisasi menurut Prihastuti (2013: 38) adalah (1) Segala informasi tidak tersaring untuk informasi baik maupun informasi buruk; (2)Pemborosan dan perilaku yang menyimpang dari adat ketimuran; (3)Lebih condong pada budaya barat sehingga budaya pribadi sering ditinggalkan; (4) Sikap individualis dan menutup diri sering terjadi pada individu yang mengikuti arus globalisasi secara terusmenerus. Masalah terbesar yang kita hadapi bersama adalah bagaimana kita menyikapi dampak negatif dari pengaruh globalisasi, sehingga kita dapat menyerap pengaruh positif dan tidak meninggalkan nilai-nilai karakter budaya bangsa Indonesia.

\section{Guru Profesional dan Permasalahannya}

Dalam Undang-Undang Guru dan dosen No 14 tahun 2015 menjelaskan bahwa Profesional adalah pekerjaan atau kegiatan yang dilakukan oleh seseorang dan menjadi sumber penghasilan kehidupan yang memerlukan keahlian, kemahiran, atau kecakapan yang memenuhi standar mutu atau norma tertentu serta memerlukan pendidikan profesi. Sementara Syakur (2012: 1) guru

professional adalah guru yang mampu dan mau menjalankan tugasnya karena kompetensi dan keterampilan yang dimilikinya, maka dapat dipahami dalam konteks keguruan bahwa profesionalisme merupakan kualitas dan mutu kinerja, serta perilaku yang menunjukkan suatu profesi guru.

Penjelasan tersebut dapat diartikan bahwa profesional merupakan pekerjaan yang memiliki keahlian, kecakapan dan standar mutu. Guru yang professional harus memiliki standar mutu antara lain memiliki kualifikasi akademik, kompetensi (pedagogik, kepribadian, profesional, dan sosial), dan sertifikat pendidik yang dapat dilihat dari kinerja serta perilaku yang menunjukkan profesi guru. Guru yang mempunyai pengakuan sebagai tenaga profesinal ini tentunya mampu melaksanakan pekerjaannya denggan profesional sesuai dengan fungsinya.

Permasalah yang kita hadapi guru yang memiliki sertifikat profesional masih belum menjalankan pekerjaannya secara professional, menurut Suryana, (2008: 2) permasalahan tersebut disebabkan oleh: (1) Masalah personal, tenaga pendidik diisi/ditempati oleh orang-orang yang tidak memenuhi persyaratan dan kualifikasi sebagai guru. Akan tetapi hal ini bukan kesalahan tunggal secara perorangan akan tetapi system memberikan andil besar untuk meloloskannya; (2) Masalah system dan manajemen, dari dulu sistem sering kecolongan dalam menjaga boundaries system pendidikan (keguruan) sebagai sebuah profesi. Struktur kendali dalam system sangat lemah dibangun pemerintah, akhirnya manajemen tidak dapat berjalan dengan baik sebagai tools system.

Akedum (1999) dalam Masri (2015) melakukan identifikasi dan mengungkapkan faktor faktor yang menyebabkan kurangnya profesionalisme seorang guru diantaranya: (1) Profesi keguruan kurang menjamin kesejahteraan karena rendah gajinya. Rendahnya gaji berimplikasi pada kinerjanya dan profesionalisme guru masih rendah; (2) Masih banyak guru yang tidak menekuni profesinya secara utuh. Hal ini disebabkan oleh banyak guru yang bekerja di luar jam kerjanya untuk memenuhi kebutuhan hidup sehari hari sehingga waktu untuk membaca dan menulis 
untuk meningkatkan diri tidak ada; (3)Belum adanya standar profesional guru sebagaimana tuntutan di negara negara maju; (4) kemungkinan disebabkan oleh adanya perguruan tinggi swasta sebagai pencetak guru yang lulusannya asal jadi tanpa mempehitungkan outputnya kelak di lapangan sehingga menyebabkan banyak guru yang tidak patuh terhadap etika profesi keguruan; (5) kurangnya motivasi guru dalam mening-katkan kualitas diri karena guru tidak dituntut untuk meneliti sebagaimana yang diberlaku-kan pada dosen di perguruan tinggi; ( 6) Rendahnya kepatuhan guru terhadap norma dan etika profesi keguruan; (7) masih belum berfungsi PGRI sebagai organisasi profesi yang berupaya secara maksimal meningkatkan profesiona lisme anggotanya.

Gambaran professional guru di atas menunjukan bahwa kurangnya optimal guru professional dalam melaksanakan fungsinya sebagai pendidik dan agen pembelajaran disebabkan oleh faktor internal yang datang dari guru sendiri dan faktor eksternal dari pemerintah yaitu dukugan dari pemerintah untuk meningkatkan kualitas dan pengembangan guru profesional.

Dengan demikian guru professional sebagai pendidik dan agen pembelajaran dihadapkan dua permasalahan besar yaitu pertama, meningkatkan kualitas profesinya sehingga bisa melaksanakan fungsinya secara optimal. Kedua bagaimana guru dalam menghadapi tantangan global sehingga mampu menyesuaikan diri dengan kondisi global untuk dirinya sendiri dan kepada peserta didik. Tentunnya guru professional yang berkualitas akan mudah untuk menyesuaikan diri dengan kondisi global daripada guru yang tidak berkualitas.

Mulyasa (2011: 11) menyebutkan bahwa untuk menjadi profesional, maka seorang guru dituntut memiliki minimal 5 hal seperti berikut ini: (1) Memiliki komitmen terhadap peserta didik dan proses belajarnya; (2) Menguasai secara mendalam bahan atau mata pelaj aran yang diajarkannya serta cara mengajarkannya kepada peserta didik; (3) Bertanggung jawab memantau hasil belajar peserta didik melaui berbagai cara evaluasi; (4) Mampu berpikir sistematis tentang yang dilakukannya dan belajar dari pengalamannya; dan (5) Seyogya- nya merupakan bagian dari masyarakat belajar dalam lingkungan profesinya.

Sedangkan pada pasal 7 Undang-Undang Guru dan Dosen menyebutkan profesi merupakan bidang pekerjaan khusus yang dilaksanakan berdasarkan prinsip sebagai berikut (1) memiliki bakat, minat, panggilan jiwa, dan idealisme; (2) memiliki komitmen untuk meningkatkan mutu pendidikan, keimanan, ketaqwaan, dan akhlak mulia; (3) memiliki tanggung jawab atas pelaksanaan tugas keprofesionalan; (4) memperoleh penghasilan yang ditentukan sesuai dengan prestasi kerja; (5) memiliki kesempatan untuk mengembangkan keprofesionalan secara berkelanjutan dengan belajar sepanjang hayat: (6) memiliki jaminan perlindungan hukum dalam melaksanakan tugas keprofesio-nalan; dan (7) memiliki organisasi profesi yang mempunyai kewenangan mengatur hal-hal yang berkaitan dengan tugas keprofesionalan guru.

Penjelasan di atas menekakan bahwa guru yang profesional mempunyai komitmen terhadap tugasnya sebagai pendidik dan agen pembelajaran. Mereka akan berusaha untuk meningkatkan kualitas pembelajaran dengan meguasai materi yang akan diajarkan, bertanggung jawab terhadap proses pembelajaran dan hasil pembelajaran, serta berusaha pengembangkan keprofesiannya secara berkelanjutan.

\section{Upaya Membangun Guru Profesional Berkarakter di Era Globalisasi Melalui Pembelajaran}

Profesi seorang guru bersifat professional. Hal ini berarti bahwa seorang guru wajib memiliki kompetensi yang professional. Kompetensi ini akan terbukti ketika guru mengajar di kelas. "Kompetensi adalah suatu kemampuan untuk melaksana-kan atau melakukan suatu pekerjaan atau tugas yang dilandasi atas ketrampilan dan pengetahuan serta didukung oleh sikap kerja yang dituntut oleh pekerjaan tersebut. Dengan demikian, kompetensi menunjukkan keterampilan atau pengetahuan yang dicirikan oleh profesionalisme dalam suatu bidang tertentu sebagai sesuatu yang terpenting, sebagai unggulan bidang tersebut (Widodo, 2009).

Pada pasal 6 Undang-Undang Guru dan dosen no 14 tahun 2015 disebutkan bahwa 
Kedudukan guru sebagai tenaga profesional bertujuan untuk melaksanakan sistem pendidikan nasional dan mewujudkan tujuan pendidikan nasional, yaitu berkembangnya potensi peserta didik agar menjadi manusia yang beriman dan bertakwa kepada Tuhan Yang Maha Esa, berakhlak mulia, sehat, berilmu, cakap, kreatif, mandiri, serta menjadi warga negara yang demokratis dan bertanggung jawab.

Berdasarkan landasan tersebut jelas bahwa guru sebagai pendidik mempunyai tugas dalam pembelajaran tidak hanya memberikan pengetahuan, ketrampilan, tetapi juga menanamkan sikap nilai-nilai berkarakter pada siswanya sehingga mereka bisa mengikuti arus global dengan tidak meninggalkan nilai-nilai budaya bangsa Indonesia. Dengan demikian keberhasilan pencapaian tujuan pendidikan sangat tergantung dari kemampuan guru dalam melaksanakan tugas profesinya.

Menurut Kunandar (2007), ada beberapa tantangan globalisasi yang harus disikapi guru dengan mengedepankan profesionalismenya, yaitu: (1) Perkembangan ilmu pengetahuan dan teknologi yang begitu cepat dan menda-sar; (2) Krisis moral yang melanda Indonesia. Akibat pengaruh IPTEK dan globalisasi telah terjadi pergeseran nilai-nilai yang ada dalam kehidupan masyarakat; (3) Krisis sosial, se-perti kriminalitas, kekerasan, pengangguran, dan kemiskinan yang terjadi dalam masyara-kat; (4) Krisis identitas sebagai bangsa dan Negara Indonesia.

Adapun uapaya yang dapat dilakukan untuk membangun professional guru berkarakter di era globalisasi melalui pembe-lajaran dapat dilakukan sebagai berikut:

\section{Kelengkapan Administrasi pembelajaran.}

Setiap guru yang profesional akan membuat administrasi atau perangkat pembelajaran yang digunakan guru untuk mengajar. Perangkat pembelajaran antara lain Silabus, RPP, bahan ajar, media pembelajaran, dan sumber belajar yang dapat digunakan untuk membantu memperjelas materi. Guru mampu mengorganisasi materi yang akan diajar dari berbagai sumber referensi sehingga mudah dipahami oleh peserta didik. Guru harus mampu memberikan contoh-contoh konkrit materi yang diberikan khususnya permasalahan-permasalah terkeni dan dialami peserta didik. Oleh karenanya guru harus bisa mengoperasikan laptop dan internet, sehingga guru mudah untuk mencari sumber materi terkini dan mengetahui perkembangan ilmu pengetahuan dan teknologi. Selain itu guru dalam mengorganisasi materi juga memyisipkan nilai-nilai karakter bangsa sehingga peserta didik tidak hanya mempelajari ilmu pengetahuan dan ketrampilan, tetapi juga nilai-nilai karakter yang dapat diterapkan dalam kehidupan sehari-hari.

Guru profesional bisa mengetahui, memilih, membuat, dan menggunakan media pembelajaran yang sesuai dengan materi yang diajarkan. Oleh karenanya guru harus bisa membuat power poin yang menarik yang bisa memotivasi peserta didik pada materi yang dijelaskan dan memudahkan pemahaman peserta terhadap materi yang di bahas.

\section{Pelaksanaan Pembelajaran}

Pelaksanaan pembelajaran merupakan implentasi dari konpetensi yang dimiliki oleh guru baik, kompetensi pendagogik, kepribadian, sosial dan professional. Kinerja guru professional selain dilihat dari kelengkapan administrasi mengajar juga dapat dilihat dari kinerja guru dalam pembelajaran. Menurut Surakhmad (2009: 304) kemampuan guru yang berkualitas: (1) Kompetensi pedagogik: kompetensi mengelola pembelajaran peserta didik; (2) kompetensi kepribadian: berkejiwaan mantap, beraklak mulia, arif, berwibawa, menjadi teladan bagi peserta didik; (3) kompetensi profesional: penguasaan materi secara luas dan mendalam; (4) kompetensi sosial: mampu berkomunikasi dan berinteraksi degan manusia sekitarnya. Sedangkan pembelajaran yang berkualitas menurut Surakhmad (2009: 354), Pembelajaran yang berkualitas memadu-kan sekurangkurangnya peserta didik sebagai pembelajaran yang berkualitas, yang difasilitasi oleh guru yang berkualitas, melalui program pembelajaran yang berkualitas, dengan dukungan ekosistem pembelajaran yang berkualitas, di dalam kontek lembaga pembelajaran yang berkualitas. Hanya pembelajaran yang berkualitas yang mampu memberikan hasil pembelajaran yang berkualitas.

Penjelasan di atas dapat diartikan bahwa dalam proses pembelajaran guru harus bisa menerapkan keempat kompetensi yang dimilki yaitu kompetensi pedagogik, kepribadian, sosial dan profesional. Penerap-an pembelajaran bisa 
berkualitas bila dilaku-kan oleh guru berkualitas dan didukung oleh ekosistem berkualitas (sekolah berkualitas, lingkungan rumah berkulitas, dan masyarakat berkualitas).

(a) Program pembelajaran berkualitas

Program pembelajaran berkualitas menyagkut dua aspek yang utama yaitu materi dan proses. Kedua ini saling berkaitan artinya materi yang akan diberikan sangat menentukan metode yang akan digunakan. Misalnya metode apakah yang lebih ampuh untuk pendidikan demokrasi kecuali mepraktekkan kehidupan demokrasi, dibandingkan menceramahkannya dalam situasi demokrasi, jadi yang tepat menggu-nakan metode praktek demokrasi. Menurut Surakhmad (2009: 359) bahwa materi yang berkualitas memiliki karakteristik (1) mengutamakan materi muktakhir yang tidak usang; (2) bervisi ke depan, tidak berfokus untuk persiapan ujian, (3) bersifat integrative, tidak terkotak-kotak dalam mata pelajaran; (4) kaya materi yang berjangkauan lokal dan nasional; (5)menjangkau isu-isu kehidupan nyata kontenporer; (6) terbuka terhadap kehidupan budaya yang multi dimensi; (7) Melibatkan isu kerukunan berbangsa dan kehiduan inklusif; (8) membahas isu kritis membangun demokrasi yang beradab.

Oleh karenanya guru professional harus bisa menengemas materi yang sedimikian rupa sehingga karakteristik materi berkualitas dapat tercapai. Selain itu, guru harus benar-benar menguasai materi yang di bahas. Guru mampu menjelaskan degan baik, sistimatis, dan memberkan contoh-contoh konkrit sehingga siswa mudah memahaminya. Tidak lupa dalam menyampaikan materi disisipi penanaman nilainilai karakter, misalnya disiplin, jujur, berani mengeluarkan pendapat, menghargai pendapat teman, bekerja keras, mandiri, dan bertanggung jawab.

Sedangkan proses pembelajaran yang berkualitas dapat dilakukan guru professional antara lain: (1) Memberikan peluang belajar kepada peserta didik tanpa diskriminasi; (2) suasana positif dan memotivasi perkembang-an individual; (3) semangat kerjasama, membagi pengetahuan sesame peserta didik; (4) peluang belajar dengan sikap pembela-jaran yang terbuka; (5) peluang memanfaat-kan masyarakat sebagai sumber belajar; (6) tatangan menganalisa, memahami, dan menerapkan hasil belajar, umpan balik secara berkesinambungan dalam menilai pembela-jaran. (Surakhmad, 2009; 359)

Penjelasan di atas dapat disimpulkan bahwa proses pembelajaran berkualitas menekankan pada memberikan kesempatan pada pesrta didik aktif dalam proses pembela-jaran, masyarakat sebagai sumber belajar, dan memberikan tantangan kepada peserta didik untuk memahami, menganalisa dan menerap-kan hasil belajar.

Proses pembelajaran pada dasarnya implementasi dari metode pembelajaran. Keaktifan peserta didik dalam pembelajaran ditentukan oleh metode pembelajaran yang digunakan oleh guru. Oleh karenanya guru harus memilih metode pembelajaran yang memberikan kesempatan pada siswa untuk aktif. Selain itu metode pembelajaran yang dipilih dapat meningkatkan kompetensi pengetahuan, kompetensi ketrampilan, dan kompetensi sikap yang mencerminkan nilai-nilai budaya bangsa misalnya, kerjasama, tolongmenolong, jujur, disiplin, kerja keras, saling menghargai pendapat orang lain, bersifat terbuka, demokratis, bertanggung jawab dan berpikir kitis dan inovatif. Metode pembelajaran yang dapat menjadi plihan misalnya metode kooperatip, metode berbasis masalah, metode berbasis proyek, dan metode descavery.

(b) Ekosistem Pembelajaran berkualitas

Ekositem atau lingkungan pembelajaran yang berkualitas dapat dilihat dalam perspektif yang sangat luas lingkungan politik, sosial, dan budaya yang berdemensi nasional maupun global. Ekosistim yang lebih sempit adalah lingkungan sekolah, keluarga dan masyarakat sekitar. Guru professional akan menciptakan suasana yang berkualitas pada ketiga lingkungan tersebut untuk meningkat-kan kualitas pembelajaran. Menurut Surakhmad (2009: 360) lingkungan sekolah yang berkualitas yang dapat mendukung proses pembel;ajaran adalah : (1) menjadi kebangaan murid, orang tua, masyarakat, guru; (2)mengutamakan minat dan bakat pribadi setiap anak; (3)mengutamakan pemahaman, pemikiran dan penemuan; (4) bertolak dari potensi murid bukan status sosial; (5) mendukung murid mencari dan membela kebenaran; (6) memupuk kepedulian anak berbagi dan bertukar pandang; (7) mendorong belajar mandiri dan berani menghadapi tantangan; (7) menghargai perbedaan potensi 
individual setiap peserta didik; (8) menjadi lembaga sosial yang menerapkan kebersamaan; menjadi lembaga berpikir dan lanbang belajar sepanjang masa; (9) menjadi lembaga pendidikan pembuda-yaan dan kemajuan; (10) menjadi lembaga pengindonesiaan berdasar keberagaman.

Sedangkan keluarga terutama orang tua dan masyarakat perlu dikembangkan menjadi komponen ekosistem pembelajaran yang berkualitas. Pemahaman orang tua dan masyarakat terhadap sekolah diyakinkan bahwa sekolah adalah milik masyarakat, bersumber dari kebutuhan masyarakat, perlu dikelola bersama oleh masyarakat, untuk kepentingan masyarakat. Dengan demikian keluarga dan masyarakat merupakan komponen ekosistem yang dapat mendukung keberhasilan pembelajaran berkualitas.

\section{Evaluasi Pembelajaran}

Guru professional selain bisa mengajar juga harus bisa melakukan evaluasi terhadap pembelajaran. Evaluasi pembelajaran dapat dilakukan ketika proses pembelajaran (nilai proses) dan selesai pembelajaran (nilai hasil). Berkait hal tersebut guru harus bisa membuat instrument penilaian berupa soal-soal dan cara penilaiannya. Penilaian yang sesuai dengan metode siswa aktif adalah menggunakan penilaian autentik. Penilaian autentik merupakan penilaian yang dilakukan oleh guru terhadap setiap kegiatan siswa. Misalnya ketika menggunakan metode diskusi guru harus bisa membuat lembar Kerja siswa berisikan soal-soal diskusi, lembar pengamatan untuk menilai diskusi kelompok dan diskusi kelas beresrta rubrik penilaian diskusi, dan pedoman penilaian pelaksanaan diskusi. Soal-soal yang digunakan bahan diskusi adalah soal-soal yang yang dapat menantang siswa untuk berpikir kritis dan analitis. Permasalah yang diangkat adalah masalah yang kontektual yang dialami oleh siswa dalam kehidupan sehari-hari. masalah yang diangkat masalah yang baru atau sedang dihadapi saat itu.

\section{Guru Profesional Menjadi teladan Peserta Didik}

Guru dalam mengajar merupakan sosok guru secara utuh, artinya penampilan guru, sikap guru, tutur kata guru, etika guru, dan cara mengajar guru dapat diamati oleh peserta didik dan dijadikan sebagai contoh oleh peserta didik. Oleh karenanya guru perlu mengembangkan nilai nilai karakter baik pada dirinya, seperti kepedulian, kejujuran, keadilan, tanggung jawab, disiplin, rasa hormat terhadap diri dan orang lain, etos kerja yang tinggi, dan kegigihan.

Guru yang berkarakter adalah guru yang memiliki nilai dan ke yakinan yang dilandasi hakikat dan tujuan pendidikan serta digunakan sebagai kekuatan moral dalam menjalankan tugasnya sebagai pendidik. Oleh karena itu, guru yang berkarakter kuat memiliki kemampuan mengajar, dan juga dapat menjadi teladan bagi pesrta didik. Artinya guru harus memberikan contoh karakter yang baik dalam pelaksanaan pembelajaran. Sebagai contoh guru menanamkan sikap kedisplinan pada peserta didik, maka guru juga memberikan contoh disiplin dalam pekerjaannya. Misalnya datang ke sekolah tepat waktu, mengajar tepat waktu, dan selalu menempati janji.

Nilai-nilai karakter yang diterapkan guru dalam kehidupan sehari-hari ini akan menjadi contoh pada peseta didik dan akhirnya menjadi sikap kebiasaan yang diterapkan sehari-hari. Karakter nilai-nilai budaya bangsa yang luhur ini akan menjadi sikap dan kebiasaan yang diterapkan dalam kehidupan sehari-hari oleh guru dan peserta didik. Kekuatan nilai-nilai positif inilah yag nantinya akan menjadi filter pengaruh globalisasi yang bersifat negative Sehingga guru akan mampu mengadopsi pengaruh positif dari globalisi (ilmu pengetahuan, teknologi, budaya, politik, sosial, dan ekonomi) untuk meningkatkan kualitas pendidikan tetapi tetap berpenggang pada nilainilai karakter budaya bangsa.

Istilah dari bahasa jawa guru "digugu dan di tiru" yang sudah membudaya di masyarakat kita memang harus diterapkan. Artinya apa yang dilakukan guru baik sikap, perbuatan, penampilan dan perintah akan ditiru dan dilaksanakan oleh peserta didik. Guru menjadi cerminan bagi peserta didik dalam bersikap dan bertingkah laku dalam kehidupan sehari-hari. hal ini sesuai slogan dari Ki hajar Dewantara "Ing Ngarsa Sung Tuladha," yang diartikan yaitu menjadi seorang pemimpin harus mampu memberikan suri tauladan atau panutan bagi orang - orang disekitarnya. Selain itu guru juga $341 \mid \mathrm{S}$ e $\mathrm{m}$ in a r P P G S M-3 T UM 2016 
bersikap Ing Madyo Mangun Karso, artinya guru mampu membangkitkan atau menggugah semangat kepada peserta didik dengan menciptakan suasana yang lebih kodusif untuk keamanan dan kenyamanan. dalam proses pembelajaran. "Tut Wuri Handayani, artinya guru memberikan dorongan moral dan semangat kerja dari belakang. Dorongan moral ini sangat dibutuhkan oleh peserta didik untuk menumbuhkan motivasi dan semangat belajar.

\section{PENUTUP}

Kinerja guru professional akan dapat dilihat dari fungsi guru sebagai pendidik dan agen pembelajaran. Guru profesiobal berkarakter akan bisa terbentuk apabila guru mengembangkan nilai nilai karakter baik pada dirinya, seperti kepedulian, kejujuran, keadilan, tanggung jawab, dan rasa hormat terhadap diri dan orang lain, serta ketekunan, etos kerja yang tinggi, dan kegigihan dan menerapkannya dalam pembelajaran dan kehidupan sehari-hari. Guru harus memberikan contoh tauladan dalam penerapkan karakter nilai-nilai budaya bangsa pada pesrta didiknya. Guru professional yang berkarakter yang dapat melaksanakan pembelajaran berkarakter dan menghasilkan peseta didik berkualitas dan berkarakter. Upaya membangun guru profesional berkarakter dapat dilakukan melalui pembelajaran, antara lain 1) kelengkapan administrasi pembelajaran yang merupakan acuan dan evaluasi pelaksanaan pembelajara, 2) Pelaksanaan pembelajaran baik dalam proses pembelajaran dan materi pembelajaran guru menanamkan nilai-nilai karakter bangsa, 3) Evaluasi pembelajaran yang merupakan kegiatan menilai proses dan hasil pembelajaran, dan 4) Guru profesional menjadi suri tauladan atau panutan peserta didik. Nilainilai karakter yang diterapkan guru dalam pembelajaran dan kehidupan sehari-hari menjadi contoh peserta didik dalam menerapkan nilai-nilai tersebut. Karakter yang sudah menjadi milik guru dan peserta didik ini merupakan filter yang digunakan untuk menyaring pengaruh globalisasi yang negatif sehinga guru mampu mengadopsi pengaruh globalisasi positif (ilmu pengetahuan, teknologi, budaya, politik, sosial, dan ekonomi) tanpa meninggalkan nilai-nilia karakter budaya bangsa Indonesia. Selain itu guru harus mampu membangkitkan atau menggugah semangat kepada peserta didik dengan menciptakan suasana yang lebih kodusif untuk keamanan dan kenyamanan. dalam proses pembelajaran. Guru juga bersikap memberikan dorongan moral dan semangat kerja dari belakang.

\section{DAFTAR RUJUKAN}

E. Mulyasa, 2011, Standar Kompetensi dan Sertifikasi Guru, Bandung: PT Rosdakarya.

Kunandar, 2007, Guru Profesional: Implementasi Kurikulum Tingkat Satuan Pendidikan (KTSP) dan Sukses dalam Sertifikasi Guru, Jakarta: Rajawalai Pers.

Prihastuti, Enis, 2013, Globalisasi Dosen Fakultas Ekonomi, Prodi Akuntansi Universitas 17 Agustus 1945 Banyuwangi. ANALISA, Vol. 1, No. 1, April 2013: 35 - 39.

Suryana, Asep, 2008, Paradikma Baru Pengembangan Tenaga Pendidik, Jurusan Administrasi Pendidikan Fakultas IImu Pendidikan Universitas Pendidikan Indonesia.

Soetjipto dan Kosasi, Raflis 2009, Profesi Keguruan. Jakarta: Rineka Cipta.

Syakur, Mahlail Sf. Professionalisme Guru Dan Globalisasi1 (Karakter Guru Professional di Era Global 17 Maret 2012. Proceeding Seminar Nasional "Profesionalisme Guru Dalam Perspektif Global Tahun 2012 ISBN: 978-602-18235-0-7.

Surakhmad, Winarno, 2009, Pendidikan Nasional Strategi dan Tragedi, Jakarta: Kompas Media Nusantara.

Undang-Undang Republik Indonesia Nomor 14 Tahun 2005 Tentang Guru Dan Dosen. 